\title{
Spenser's Redcrosse Knight: Despair and the Elizabethan Malady
}

\author{
DONALD BEECHER
}

In Canto ix of the first book of The Faerie Queene, Spenser's Redcrosse Knight encounters Despaire. The episode is a perfect case in point with regard to the relationship between contemporary ideas and literature. At a primary level of enquiry, despair requires no special commentary, for is it not the abandonment of hope which leads to despondency and suicide, much as the term would be understood in any age? Of necessity it must be. Yet Tudor thinkers had granted to despair a special significance through their own theological and medical systems, its unique power to threaten both the secular as well as the spiritual life. Their view of the fundamental condition of man included a greater sense of his vulnerability to this temper, a vulnerability confirmed by behaviour. The encounter with Despaire, it could be argued, is both the dramatic turning point of Spenser's narrative and the pivotal event in the education of his Christian Warrior, structural decisions predicated upon clear and decisive ideas about the nature of despair and its place in the generic Christian experience. ${ }^{1}$ Joylessness and despair are, for Spenser, not only simple truths in the range of human emotional responses, but also complex "ideas" with complex histories.

Spenser's challenge was both to represent those concepts dramatically as they were understood, and to deal with the complex question of causes. $\mathrm{He}$ had to reveal, in a fully representative way, the circumstances in the inner life which lead men to despair of God's grace and to pronounce doom upon themselves. He had to demonstrate that continuum of associations accounting for the spiritual decline which begins with boredom and listlessness and passes on to guilt, despondency and suicide. Of those associations and the causal relationships between them, Spenser made narrative virtue. Yet his juxtaposing of ideas entails at least technical violations to the compartimentalized treatments they had received from the Tudor expository book writers, a fact requiring careful examination. Critical to the point is that Spenser approached his subject as an encyclopedist, so that in his representation of despair, he was prepared to draw upon as many of the literary and intellectual contexts concerning that 
perilous temptation as possible in order to complete, in Redcrosse, his portrait of the archetypal spiritual experience. Only his composite system of abstractions, narratives and revealed characters together completes the essay. Spenser derived his treatment of the ideas from the theological and medical writers, as well as from the drama of the period. Though he had to make very specific, and, for the interpreter of ideas, very meaningful choices regarding that spiritual state and its causes within the context of the received ideas of his age, yet he could not, in the case of Redcrosse, content himself with a monodimensional representation of the despair motif.

In accordance with the temper of his times, Spenser must have looked upon religious despair as one of the greatest occupational hazards of the mentally militant Christian, and a constant menace to the serious spiritual venturer. He would have viewed such an idea as an eternal verity of the spiritual life, being less in a position than we to see that its importance was relative to the degree of emphasis which his age placed upon sin, guilt, fear of damnation, sensitivity to spiritual dryness and tenderness of conscience. In the thought frame surrounding Redcrosse Knight, how could spiritual joy and zeal in God's service not have, as its most devastating enemy, the very loss of that joy and zeal? In making despair so besetting a woe, Spenser adds a decisive element to his portrait of the knight as a generic figure, revealing in action the woes of the rigorously cultivated inner spiritual life. The component parts of his life-as-journey mark the moments of crises in his transformation from the world renouncing but spiritually unseasoned warrior to the man of perfected faith, humility and religious joy - those essential qualities which would arm him internally for the ultimate fight against the dragon.

Spenser's age did not invent the metaphor of combat that characterized the spiritual life but his age was inclined to give that metaphor such reality in their imaginations as to make of it the essential nature of the soul's existence. The Christian in his constant warfare against temptation, even the most secret and hidden, was thought of as a warrior, clad in his Pauline armour, engaged in a lifelong struggle with sin. In this structure, the writer found not only a vehicle for warning against visible and declared temptations, but also for anatomizing the peaks and valleys of the spiritual psyche in confrontation with its own incapacity to maintain a state of constancy, purpose and fulfilment. In fact, it is this inward combat of the self with its own levels of spiritual fatigue that is Spenser's primary concern. Whereas his literary forebears had been concerned with the overt sins of the flesh and of defiance against law and righteousness, Redcrosse, as holiness in a state of becoming, is not a moral renegade rescued from wordly depravity, but a well-intentioned spiritual seeker whose very will constitutionally fails in its determination to pursue right spiritual goals. That inherent 
lassitude is at the foundation of Redcrosse's psychodrama. Herein is depicted the paradoxical conviction, that suffering, even to despair, alone could lead fallen man to the knowledge of the good, yet that such suffering, arising from man's own fallible nature, could likewise lead to damnation. Critical then to the soteriological views of the age was this management of despair. Salvation was related to a psychological process.

Following that metaphor of combat into the rhythms and psychological contours of the spiritual life, there emerges the figure of the warrior, imbued with a sense of mission, both to fight dragons and to preserve holiness as a state of mind, ostensibly two separate activities, which are, in fact, one. This sense of the spiritual life was part of a deeply implanted teleological fixation. The progress of the soul was attached to the menace of time, to the quest for spiritual guerdons and to a constant monitoring of the forces within which kept the life pure and on course. The struggle with joylessness was inevitably conflated with anxieties over doubt and guilt. In Spenser they are never entirely separate from one another, and thus the complexity of his portrait. With the intensely personal preoccupation with the destiny of the soul, there arose a correspondingly solipsistic anxiety over both guilt and doubt. Where spiritual joy was lacking, the prospects of God's rejection were never far away. Emotional torpor transposed itself, by auto-suggestion, into a morbid preoccupation with guilt, doubts of salvation, and death. In that maelstrom of uncertainties and recriminations, despair took shape as the darkest and most terrifying enemy of the soul. Christian militarism in the Protestant mind had taken a perverse turn inward upon the psyche, and that morbid introspection was seconded at the level of ideas by the scientific enquiry into the diseases of the soul conducted by the physicians. Spenser was faithful to the "psychology" of his age in making the despair episode the nadir of the paradigmatic journey. Only a sense of this interlocking pattern of ideas can account for the ideological force contained in the parts. Despair had, in this sequence of conditions and consequences, risen to the level of an idée force, a selfcreating reality, in the spiritual life of the age.

The encounter with Despaire (in Book I Canto ix of the Faerie Queene) is one of the best known episodes in Spenser, made particularly memorable by his careful painting of the doleful scene: the "hollow caue," the "craggie clift," the "carrion carcases," the "ghastly Owle, / Shrieking his balefull note," the desolate landscape littered with suicide victims hanging from stubs of trees. ${ }^{2}$ Spenser's instincts as a poet in characterizing the figu re as a ragged old man, dwelling hermit-like in his cave, are entirely confirmed. Despaire could be no ordinary adversary whom Redcrosse might bash with sword or pike in the usual combative way. In this hermit, the conscience-stricken soul meets the voice of its own inadequacy, the cunning sophister who touches the most secret and vulnerable parts of the 


\section{ERRATA}

106 / Renaissance and Reformation

mind. His warfare is entirely rhetorical and psychological; in this way he can disarm the warrior far more effectively than by force, for despair, translated into psychic values, has no power outside of the mind, which is its own tormenting accuser. Despair is not only a confrontation with hopelessness, but a.loss of courage that makes resistance impossible. Citing past sins and the necessary justice of God, this voice urges death as the only escape. At the close of his peroration, Despaire offers to the conscienceburdened knight the hanging rope and the rusty knife. Spenser's first mode in the anatomy of an idea is poetic, in the creation of a symbolic landscape which is a correlative to the inward horrors of the despondent man. ${ }^{3}$

Spenser's second mode in dealing with despair is the exploitation of its inherent drama. What despair means is precisely what is conveyed by the format of the debate. The figure of Despaire is a conventional projection of the soul disputing with itself the fundamental worth of the spiritual struggle. The rhetorical structure of the episode is perfectly clear. Spenser's Despaire, in keeping with literary tradition, labours to destroy all faith in Christ's mercy. He quotes scripture selectively in order to dwell morbidly on the inexorableness of God's anger: "Is not his law, Let every sinner die:/ Die shall all flesh? (I. ix. 47. 5-6; Job 34:15). The words stick in the hero's heart. The direct encounter with his own failures leaves Redcrosse so dismayed "That naught but death before his eyes he saw / And euer burning wrath before him laid,/ By righteous sentence of th Almighties law:" (I. ix. $50.2-4)$. The self-recriminating conscience succumbs to the half-truths of spiritual temptation, insisting upon an execution of justice against the sinful creature. Despaire does his work upon the soul by logic, urging those interior reflections which suggest suicide as the only consistent and meaningful response. The fundamental outline of that drama is always the same. By fixed convention, the despondent hero meets a grisly personification of his own inadequacies, debates the condition of the soul with this adversary, loses the debate and sinks into wan hope. At this juncture, the helpless victim either takes his life, or is quickly drawn away by some loyal companion, some affirmative voice in the psyche. This guide arrests selfviolence and preaches the strength of God's mercy.

The literary sources of this dramatic sequence can be in little doubt. Despair as a personification, with his halter and knife, was a central figure in the Tudor morality play and interlude. As far back as Skelton the scenario was fully formed. The question of specific sources for Spenser is quite irrelevant since the motif had become commonplace; any representation would have served as well as another. Skelton's Magnificence, an interlude written in 1516 while he.was Orator Regius to Henry VIII, could very well be the founder of this profile of the despair encounter tradition in the popular drama, (although aspects of despair had made their appearance before as in The Castle of Perseverance (1350-99) when Justice begs God 
not to extend his pity to mankind, but to leave him in hell with his sins as the law demands). Magnificence is a prosperous ruler who gives himself over, by degrees, to acts of folly and thriftlessness until he is confronted, at last, by a state of total adversity and misery. The figure of Despair arrives in due course with his message of hopelessness:

In God's mercy, I tell them, is but folly to trust;

All grace and pity I lay in the dust. ${ }^{4}$

Curiously, the theological dimensions involving God's mercy and the fading prospects of redemption appear as the results of losing worldly power and riches. Yet by a conventional process of associations, hopelessness brings despair, and despair is never without spiritual consequences. Danger to the spiritual being is causally attached to misfortunes in the secular realm. Conversely, whom God spurns He shows no worldly favours. Thus despair will serve as the common denominator between a ruler who has lost all worldly power and an ascetic warrior who has sinned against eternal truth, consorted with false doctrines and lapsed into a state of spiritual lethargy. Both, in their despondent moods, seek death, thereby denying God's mercy and grace. Both have erred in the sight of God in squandering their talents, turning their consciences against themselves in this final act of perverse justice.

And so ungraciously thy days thou has spent,

That thou art not worthy to look God in the face.

Magnificence replies that he looks to have no part in God's grace, and Despair responds:

No, no, for thy sins be so exceeding far,

So innumerable and so full of despite,

And against thy Maker thou hast made such war,

That thou canst not have never mercy in his sight.

(Stage 4. Scene 31)

Mischief enters here to offer the familiar halter and knife, the latter of which was chosen for the final deed. He is saved by the timely arrival of Goodhope, who lectures on the sin of suicide and the axiomatic truth of God's mercy. Humility, contrition and repentance follow, and as a result of a thriftless and wayward life leading to despair, the ruler is brought, not to renewed political judgement, but to salvation. That transition of values, proceeding from wordliness to spiritual redemption through the valley of the shadow of death was an idea already clearly shaped and stated in Skelton's allegorical design. The play serves, without need of much critical 
intervention, as a commentary on the Spenserian sequence. In the morality play, as in the Faerie Queene, the rescuing scene is mandatory, serving as both the psychic and dramatic turning point. The formula was so entirely satisfactory as a representation of the spiritual struggle preoccupying the age that it dominated the dramatic structures of the age as well. Despair was the epitome of the spiritual crisis that must lead either to damnation or salvation. Any vice or temptation could serve to bring on the critical moment, but the spiritual contents of the ensuing doubts were, paradoxically, always the same.

In Wapull's The Tide Tarrieth No Man (1576) it is Wastefulness who comes to despair, and who, in the end, is redeemed like a prodigal son.

I know it is folly unto God to call,

For God I know my petition will shun,

And into perdition I am now like to fall.

Despair, despair! ${ }^{5}$

When he thinks of God's mercy, Despair reminds him that his sins are so manifold that they are beyond God's mercy: therefore, death is best. In due course Wasteful agrees and states he will seek a place where "I may/Finish my life with cord or with knife, / The dispatch whereof I will not delay." This time Faithful appears, "plucketh him again," and reminds him of mercy and the need for repentance and faith, offering to serve as a spiritual guide. Indeed, Faithful makes him kneel on the spot and repeat line by line an exorcism asking God to banish "That wicked monster of Despair." Spenser had in these plays more than a few clues. He had models for the allegorical procedures, the substance of the debates, the conventional implements, the sudden reversals and the images of mental despondency. $\mathrm{He}$ had the profile, simultaneously, of the received notions pertaining to the psychology of temptation and despair, and the place they held in the larger scheme of redemption or damnation.

Despair is an odd assailant, because he has no means of his own to inflict bodily harm. He is, rather, the sly sophister who preys upon his victims with a logic of insidious self-accusation that leads, in turn, to selfviolence. To the warrior who would slay dragons, he offers the rusty knife of suicide. But for all that, he is understood to be the most treacherous and dangerous of adversaries. Never do these dramatists suggest that despair is a mere provocation to meditation, or a precalculated dimension of a selfdirected process of spiritual renewal. There is a critical difference between despair as that darkest night of the soul, and the cultivated dark night of the Spanish mystics. ${ }^{6}$ To be sure, many were saved through their encounter with despair, since by that means they were brought to contrition. But every means was employed by the dramatists to reveal the true peril of that 
state which, though it may hurl one to God, is not a simple examination of conscience; it is a profound state of sin, for in that state the very grace of God is confounded.

Marlowe, it is agreed, provided the most forceful dramatic representation of the soul damned by its own despair. ${ }^{7}$ But Faustus was not without numerous forebears in the dramatic tradition. In The Tide Tarrieth No Man, Wastefulness is saved, but Greediness becomes enraged, abjures God and dies in "great madness," which death takes him "straight into hell." "Despair upon him hath wrought his will." 8 The conflict of Conscience a play by Nathaniel Woods written in 1581, is perhaps Marlowe's most worthy predecessor for thematic intensity, if not for poetry. It is a potent dramatic statement of the horrors of a mind incapable of responding to the promises of salvation. God's mercy and God's wrath, in binary union, form a driving concept of the age, and that God's mercy exceeds his wrath was a doctrine often lost in the zealous preaching of the Puritans. ${ }^{9}$ The play undescores man's freedom to accept or reject that grace. In Philologus' struggle with the stagnancy of his soul, the dimensions of this "Mankind's" tragedy take shape. He grapples with sin, election and damnation, finds himself among the reprobate, his will frozen by Calvinist obstacles. He identifies himself with Cain, Ham, Saul, Judas, Bar-Jesu and Julian the Apostate. ${ }^{10} \mathrm{He}$ is haunted by perpetual grief and fear, and by "God's just anger." Repeatedly he asks for a sword, and in the end, hangs himself with a cord. Against all good counsel, against every doctrine of comfort put to him by his friends, he was determined to die. There is a new dimension of intellectual rigidity, an entrenched emotional stubbornness, a refusal even to indulge in the futile and meaningless gestures of prayer and contrition. Philologus runs the full course of apostasy and of "deep despair," not out of belligerence or atheistical self-assurance which steel the soul in false comfort. Rather, he is a man despised in the eyes of God because he had sold his soul to wickedness and could not bring himself to accept God's grace.

The preoccupations of the dramatic tradition are relatively central and consistent. There was a fixation upon the crisis of conscience, that peculiarly Protestant voice which turned upon the self in accusations of unworthiness, whipped up by a heightened recognition of man's depravity and God's just wrath. The man of injured conscience who abandons all hope enters upon the prospects of suicide. In the struggle for perfection, the Christian must maintain an unflagging state of mental continence, labouring always to appease a God whose ire could manifest itself at any moment. Living as a spiritual Spartan meant refining one's alertness to spiritual dryness and barrenness as a sign of God's disfavour. Despair shadowed constantly that frame of spiritual conduct. But while these literary sources supply all that Spenser needed to know about the trials of the tender conscience, the psychodrama with despair, and the danger 
posed to the health of the soul and the prospects of salvation, they do not sound all the resonances of Redcrosse's spiritual nature, for Redcrosse comes to despair, not out of the loss of wordly fortune and prestige, nor out of a long debate over the power of God's mercy, though he is overcome by an awareness of his own sin and unworthiness, but rather out of a weakness in his own nature which was itself the product of a separate complex of ideas current in the age.

***

Spenser recognized that while all men are subject to the torments of despair in response to the burden of sin and God's ire, temperamentally, not all men are inclined to take so pessimistic a view of the world or of their own condition as to bring them to suicide. ${ }^{11}$ That degree of despondency must be allowed for only in psyches inclined to negative thoughts ranging from drooping spirits to pathological moroseness. We recognize in Redcrosse Knight an exemplary man, though fearfully inexperienced. We know him to be qualified in every way to become the true Christian hero. Yet in characterizing him Spenser explains:

Right faithfull true he was in deede and word, But of his cheere did seeme too solemne sad;

$$
\text { (I. i. 2. 7-8) }
$$

Joylessness was to become his most perilous weakness; it is not without characterological accuracy that the battle with Sans joy was nearly his last and that the "paynim" smote him so hard upon the crest "That twise he reeled, readie twise to fall;" (I. v. II. 6). Redcrosse was compelled to shake himself out of a "snowing dreame" in order to deliver himself from that fight. Equally significant, he was not able to slay his foe; Sans joy, merely wounded, effects his escape, and finding treatment for his wounds, prepares himself to return another day to the field of battle. The struggle with noisome joylessness was not over. Despair was, for Redcrosse, the trial at the very centre of his being, deriving from his incapacity to maintain true Christian joy.

Clearly, for Spenser, this tristitia was not a question of social demeanor, but rather a condition of the soul which obstructed the spiritual good. It was a state of torpor, of lassitude that relaxes the will, sapping the desire to carry on with the spiritual enterprise. Its secular counterpart, as represented in such humanist school plays as Wyt and Science, was tediousness, that force of ennui which distracts the scholar from his books and throws him into a state of sloth. Redcrosse's despair arises, then, not only from his immediate sense of worthlessness and rejection, but more fundamentally from a psychological predisposition to joylessness which was both an 
inherent part of his nature and a product of his specific conception of the spiritual life. At this juncture the theology of sin and medical philosophy are forced into an uncomfortable coalition, as they had been throughout the Middle Ages.

Joylessness in the religious life was a well-established idea in the writings of the churchmen, traceable as a formal topos as far back as the De institutis coenobiorum (c. 415-20) of Cassian. The sin of acedia was one of the most elusive to deal with precisely because it was a sin of temperament, of flagging emotional and intellectual interest in the spiritual life. The church writers understood it to be a condition of the soul and of the will, but its proximity to the feelings of lassitude or defeat which ensue from failure in any worldly endeavour suggested secular applications of the term from the twelfth century onwards. Moreover, the concept of spiritual torpor was perpetually exposed to explanation in medical terms which placed the origins of that temper in the constitution of the body, an interpretation which risked making the sinner no longer a violator of God's laws, but a victim of his own psychic imbalances. Spenser's Redcrosse Knight is a fit candidate for description in terms of that sin of acedia, for his malady is, in essence, a Protestant equivalent of that joylessness which beset the early cenobites, making allowances for the very great differences in historical circumstances.

In the order of narrative, in the juxtaposing of episodes which relate to one another as a sequence of causes to a final effect, Spenser reveals this tendency to acedia, this state of spiritual torpor, as the dominant weakness of his prototype of the Christian warrior. Such an interpretation of essences in the religious pilgrim cannot be overemphasized. Yet the sin of acedia, in a historical sense, can have had no direct influence upon Spenser - not in terms of a formal idea. Protestant writers were little inclined to take their theological ideas from the schoolmen. But more important, the idea itself had lost its force as an explanation of experience and behaviour well before the sixteenth century, even in Catholic countries. The concept left its mark upon the early Renaissance only as an indicator of a general woe, a kind of philosophical ennui. In that secularization of acedia, and through the intellectual legacy it created, Redcrosse derived certain of his ideological roots.

Acedia was never a fixed idea at any time during its history from the fourth century writings of Cassian to the codifications of St. Thomas. Reinhard Kuhn, in his study of ennui in western literature, traces its origins to the anchorites who sought spiritual fulfilment through isolation in the desert. ${ }^{12}$ Even there, however, away from all distractions, they found themselves vexed by their own mental inconsistencies, victims of indolence or a sense of spiritual defeat. Acedia belonged, by its very definition, to the preoccupations of the ascetic life, a life devoted entirely 


\section{2 / Renaissance and Reformation}

to the achievement of uninterrrupted spiritual elation.

The sin of sloth identified a wider range of indolence in spiritual matters with the rise of monastic communities. It was a term for all circumstances. The cenobites likewise sought a quality of the inner life charged with the emotions of spiritual achievement. Their highest ideal was to invest each mundane activity of the day with joy. Acedia denoted a lack of will to carry on with that service; it signified boredom with matters spiritual. ${ }^{13}$ According to tradition, this torpor came upon them most forcefully during the midday hours of repose, and thus the phrase by which it is remembered: the demon of noontide. This was a sin peculiar to the monastic life. Only the search for ecstatic spirituality as a daily habit of mind could provoke the morbid introspection, the despair over spiritual dryness, that resulted from sloth. The sequence is perfectly paralleled in the Faerie Queene, allowing us to conclude that even where the history of the idea forbids ascriptions of influence, similar constructions of the goals of the spiritual life, intent upon the constant maintenance of energy and will for religious duty accompanied by a corresponding state of joy in service, will produce analogous threats to that state and analogous miseries in failure.

Though acedia as a religious concept died with the close of the Middle Ages, there was an indirect course by which the medieval doctrine of sloth made itself felt during the Renaissance. By the fourteenth century, the idea "acedia" had infiltrated secular thought. Even in the most orthodox definitions of spiritual listlessness, there was both the sin of the will and the idiosyncratic state of the psyche. The church doctors called it tristitia de bono spirituali, an inexplicable sadness in the face of spiritual good. ${ }^{14}$ It is a refusal to rejoice in the manifest love of God, that fundamental joy for which man is created. So defined, acedia had progressed more than half way from the spiritual depression of the anchorites toward the recalcitrant soul which refuses to enjoy its own election into the invisible church. No two manifestations of despair could be more removed historically, yet the joylessness arising from the rejection of spiritual good joins them by association and analogy. Acedia and despair share common origins within systems of psychic spirituality which were intensely introspective and self-critical. Moreover, this tristitia in the presence of the desired good, as defined by the schoolmen, gave oblique voice to the quasi pathological qualities, the irrational element behind the uncontrollable grief. By degrees, acedia gravitated toward medical, rather than theological definition. ${ }^{15}$ Thus it was that during the thirteenth and fourteenth centuries there had been a progressive secularization of the concept, so that the vice which began as a lack of devotion, sleepiness in services, boredom with monastic duties and indifference to salvation came to mean joylessness in the most comprehensive sense of the term. In that process, acedia lost its identity as a coherent religious idea, yet it made its contribution to the Renaissance 
interest in pathological grief. ${ }^{16}$ The concept of joylessness drawn upon by Spenser was a product of this metamorphosis of a central medical idea.

Petrarch's Secretum, written in 1342-1343, cannot go unmentioned as at least an indicator of the transformation of the medieval idea of acedia into the Renaissance idea of melancholia. ${ }^{17}$ Scholars of the Italian Renaissance and of European religious history remain divided as to its specific import with regard to medieval theology, whether Petrarch used his terms properly, whether he is in agreement with Dante and a maze of related considerations. There is always a danger in suggesting that one work or another was responsible for overhauling an idea or of single-handedly reshaping intellectual thought. Yet several observations about the work enjoy general consent, pointing to the fact that it was a watershed treatise in terms of Renaissance thought. Petrarch took the term acedia, at the time of the writing of the Secretum, to mean tristitia or sorrow. His innovation is in writing a series of personal confessions in the guise of a religious treatise which is, nevertheless, not a conventional devotional book. He is nolonger even primarily concerned with the woes of the inner life related to spiritual goals. Rather he turns to concerns of love, wealth and the search for fame, general restlessness, boredom and the futility which life held, the vanity of all wishes, the world-weariness of a man defeated on every front in his personal, professional and creative life. In the name of acedia, sorrow extended to a pathological loathing for the human condition itself, a cumulative reflection upon the miseries of the past and the inevitable grief to come. With his essentially secular application of the term came a new ethos of thought; Weltschmerz was born.

Franciscus, the persona of Petrarch in the dialogue, denies the assertion that nobody can be unhappy against his will; unhappiness lies as deeply as the constitution of the mind itself. It is a fundamental complexion which renders life miserable in a way leading to despondency and death. To the end of the treatise, Petrarch remains true to the "disease," offering no salvation. It is a confessional rather than a devotional work and does not terminate with an act of contrition. Fransciscus discusses his agony in terms entirely familiar to theologians, but he anatomizes with curious intent those days and nights of torture, those darkened states of the mind which held him in thrall, finding himself, at the same time, possessed of a certain morbid pleasure in these contemplations, a manifestation of the voluptas dolendi which characterizes, likewise, the writings of the erotic melancholiacs. Petrarch gave voice to the psychological dimensions of that inexplicable grief in his vision of pervasive melancholy. It was an idea of reality which was to enjoy a full flowering in Renaissance thought.

Siegfried Wenzel allows that certain seventeenth-century writers looked upon acedia as the "medieval forerunner of what the called 'melancholy'."18 There can be little doubt that there was a relationship in terms of ideas, 


\section{4 / Renaissance and Reformation}

though melancholy was a complexion deriving essentially from medical philosophy and the humours, whereas acedia belonged to theology as a vice of the soul. There was the tendency towards contamination even in theological works, however, because joylessness and despair cannot be divorced from their causes, and these causes are invariably perceived as arising from humoural conditions affecting the psyche. The Franciscan David of Augsburg, about the middle of the thirteenth century, writes of acedia that "it inclines to despair, diffidence, and suspicions, and sometimes drives its victim to suicide when he is oppressed by unreasonable grief. Such sorrow arises sometimes from previous impatience, sometimes from the fact that one's desire for some object has been delayed or frustrated, and sometimes from the abundance of melancholic humors, in which case it behooves the physician rather than the priest to prescribe a remedy." 19

In the sixteenth century that relationship of ideas had come full circle. The philosophy of melancholy had captured the popular imagination to the extent that later observers have referred to it, with justification, as the Elizabethan malady. He who was not so by nature studied to assume the virtue. It was both a social mode and an auto-suggestive reality touching men of a wide diversity of professions and persuasions, men who wrote of it as their mental bane or the stamp of their genius. As a condition arising from medical philosophy, it was now the turn of the physicians to anatomize and offer up their cures for a variety of melancholies including religious despair. The secularization of acedia had given impetus to the spread of this new Weltansicht. Theories on melancholy would be called upon to explain despair - that persistant condition of the religious life, and a condition central to the Protestant religious experience.

If the taedium vitae and tristitia of the schoolmen found their counterparts in Renaissance theories of melancholy, there were, nevertheless, difficulties in accounting for such spiritual states in medical terms. That fact did not stop the popular mind from grouping more experiences than logic would allow under the favoured terms of the age. Nor would it stop a compulsive encyclopedist like Burton from collecting, in his summa of melancholy, a sizeable section on religion. In a technical sense, then, Spenser's Redcrosse Knight, in terms of the ideas of the age, could be suffering neither from acedia, because the concept no longer existed per se, nor could he be suffering from melancholy because no state of sin can be a condition of the complexions, thereby removing sin from the sphere of the will. What we have, in fact, is generic mankind subjected to a despair with Calvinist dimensions, brought on by a condition of joylessness which, by dint of the religious intensity of his spiritual goals had more in common, as an idea, with medieval acedia than with medical theory. Yet in terms of the received idea, Redcrosse's character could be perceived, in the Tudor context, in no 
other way than as a product of melancholy. There seems no way of escaping this impasse except to endorse the commonplace ideas as models, the portrait as a popular one, and the whole of the character as a composite sequence of contradictory ideological parts which nevertheless anatomize the psyche moving through the various phases of its testing and salvation, and in doing so relating heterodox cause to effect.

The physician Timothy Bright in his treatise on melancholy (1586) consecrates a long section to religious depression in which he produces the typical rapprochement between the despair of the Protestant conscience tormented by God's ire and medical theories concerning the psyche. His analysis is typical and representative of the attitudes of his era. Spenser would (and very well could) have found in Bright a corroborating voice for his emphasis upon the fear of God's vengeance as the most dispiriting of human conditions, one from which a man could barely extricate himself without stout spiritual resolve and spiritual guidance. In Bright's description of the dies irae Spenser would have found a more psychological treatment of the central dramatic crisis of Everyman, the struggle against temptation and loss of faith, such as it was graphically set forth in the popular moralities and interludes from which Spenser borrowed both substance and structure for the despair episode. Likewise he would have found an association between the despondent nature and the theological crisis which characterizes this event for the sin-burdened pilgrim. Yet Spenser is unconstrained to observe the reservations put upon melancholy as a cause for that despair, following as he does the logic of popular thought, which allows his knight to deal first with a spirit of joylessness before falling into doubt and suicidal longings. Bright contended more theoretically with the problem, concluding that melancholy could only be a product of despair and not its cause, though before he is finished he comes very far back toward commonplace assumptions.

Religious despondency, according to the physicians, differs from true melancholy because it seizes directly upon the soul, which is the "seate of wisedome it selfe," without passing through the system of the humours. ${ }^{20}$ This attack of the afflicted conscience produces a sense of eternal "separation from God's favour the creator and blesser of all thinges, the fountaine of all peace and comforte... ."21 Melancholy arises from fears that are but fantasies of the deranged imagination. Despair is a product of the very real threat of the soul's damnation. Melancholy produces altered complexions, thick and impure blood, the obstruction of the free course of spirits and the vapours which take hold of the fancy. In religious despair the body is not diseased, the heart "well compact and resolute." It is a state arising not from the humours, but the "mindes apprehension." 22 Therefore, "no medicine, no purgation, no cordiall, no tryacle or balme are able to assure the afflicted soule and trembling heart, now painting (sic) under the terrors 


\section{6 / Renaissance and Reformation}

of God." ${ }^{23} \mathrm{He}$ makes distinctions, out of necessity, that the corrupted imagination not be the cause of the tortured conscience. The mind charged with vapours cannot be offered as an excuse for failing to avail itself of the grace of God. The soul can be but sin sick, which is a disease in metaphor only, and that can be cured only through the offices of the Great Physician. But Bright's analysis was undoubtedly too sophisticated for the current stock of ideas. In ready terms, apparent psychological states required psychological and thus humoural causes; religious moroseness was made to share in the common Elizabethan malady. The idea had too much force to be escaped.

Robert Burton dutifully registered those necessary discriminations, but joined in the common chorus: "much melancholy is without affliction of conscience, as Bright and Perkins illustrate by four reasons; and yet melancholy alone again may be sometimes sufficient cause of this terror of conscience." ${ }^{24}$ Bright, himself, concedes that a man of melancholy complexion who also suffers from spiritual anxiety and terror, will suffer all the more, though only faith in the sufficient grace of God can rectify a condition aggravated by melancholy propensities. Then too, once the stricken conscience takes hold of the man, it can produce all the symptoms of melancholy, afterward affecting the blood, wasting the spirit, turning by degrees into true melancholy. ${ }^{25} \mathrm{All}$ men are sinners and subject to a chastizing knowledge of their guilt and shame in the eyes of God, without which no salvation, but melancholy persons are "more than any subject thereunto." 26 We are not certain that Bright has not returned us to where we began, since, in the terms of the age, what influence could possibly account for the difference between those who examine their consciences in a way that leads to faith, and those who fall into despair, unless it is precisely the presence of this melancholy disposition? To be precise, it should be called natural melancholy, as distinct from an adust state which arises only when the humours have been burnt by the passions of despair. By those means the theory is rescued and made applicable to the religious state without interfering technically with the freedom of the will. Despair, in the popular mind, could only come to those who are constitutionally predisposed to fall into despair. There the argument must rest, since, as Bright concludes "touching your particular estate... you are to esteeme of it, as mixed of the melancholick humour and that terror of God. ... "27 De facto, melancholy was allowed to play its part in the creation of that ambiguous but essential crisis which was at the centre of Protestant theology, that moment of affliction for sin which anticipated all prospects of salvation or damnation.

***

Bright is far more eloquent on the subject of God's wrath than he is on the listlessness and torpor that takes the warrior, through his own failure of 
courage and interest, away from the good fight of the faith. Spenser, as previously discussed, does not ignore that side of his hero's melancholy disposition. Una's task throughout the book is to quicken and strengthen him for his final encounter with evil; he is a knight in training, training which requires steady emotions, perseverance in the tasks at hand and purity of heart. These are the virtues in a self-monitoring and spiritually militant religion engaged daily in the defeat of personal sin. In Una's absence, Redcrosse loses the vision and abandons himself to the waters of luxury and indolence, the fountain of "pleasaunce" where Duessa finds him "Disarmed all of yron-coted Plate," listening to the distracting music of the birds and drinking of the waters which assailed his courage and sapped his manly powers." 28 This boredom with duty, and this temptation to luxury must also have their part in the course which leads a man to despair. When Burton comes to his study of religious melancholy, the term had taken to itself, by a process of definition, classification and causal relationships, not only the sin-sick soul and the affliction of conscience, but the joylessness of acedia, the paralyzed will and the loss of pleasure in the spiritual life. Burton gave a rationale, after the fact, for the cementing of both dimensions of despair in a continuum of ideas related by association. When Redcrosse is resurrected from the oubliette of Orgoglio's castle, he is not only the dead man returned, but the complete realization of the wasted melancholiac: "The cheareless man, whom sorrow did dismay,"(I.viii.43.7). Spenser was sure in his juxtaposing of episodes. We have no explanations for the suicide attempt in Canto ix other than those given in the passage itself, yet it is difficult not to consider the despair episode in light of the grim months spent in the dungeon. Arthur and Una found him there with "sad dull eyes deepe sunck in hollow pits," (I. viii. 41. 1) entirely "berobbed" of himself. Una reminds him of the contribution he had made to his own plight.

But th'onely good, that growes of passed feare, Is to be wise, an ware of like again.

(I. viii. 44. 5-6)

Redcrosse had yet to gain control over the melancholy that haunted him; there was yet a major encounter to come in which that besetting condition was to be the central issue, namely the encounter with despair. It is to be the ultimate encounter with his own temperamental weakness.

Pauline Parker observes: "It was the myth of the Puritans that the inventor of laughter should admire long faces, Puritans who had forgotten that the blessing upon the mourner is that he should mourn no more." ${ }^{29}$ Spenser is assuredly incorporating a sidelong view of this affectation. "Selfregarding melancholy is an associate of pride, and a real menace to the spiritually minded." ${ }^{30}$ In the Orgoglio episode, melancholy makes its own 
prison and pride is the lord of that castle. Spenser, however, goes beyond reference to mere spiritual affectation in making loathed melancholy an integral part of Redcrosse's nature. Thus it is that the encounter with despair, though a detached sequence of its own, is the trial not only of a diseased conscience but of an unsteady and pessimistic complexion.

\section{Carleton University}

\section{Notes}

1 Roger Sale takes an ironic view of the education of the hero. Although Redcrosse goes through the conventional motions as the good warrior in battle with adversarial powers, yet he is perpetually baffled in terms of knowing good from evil, baffled by error and by soph istry. There is a final sense in which there can be "really, no education for the Red Crosse Knight because the presumption of such an education would be that one can learn to defeat evil and be holy once for all." "Spenser's Undramatic Poetry," Elizabethan Poetry Modern Essays in Criticism, Ed. Paul J. Alpers (New York: Oxford University Press, 1967), p. 439. Or as A.S.P. Woodhouse states it: "The education of Redcross Knight differs markedly... from Guyon's. It proceeds by trial and error - principally by error: indeed until his entry into the House of Holiness he appears to have learned almost nothing... " The one lesson is "the bankruptcy of the natural man and his utter dependence for spiritual virtue upon the grace of God." "Nature and Grace in The Faerie Queene," Elizabethan Poetry, p. 354. Nevertheless, Redcrosse is a candidate for redemption, and the profiles of his adventure mark the key points in the journey toward salvation, with all of the emotional crises that come to him in moments of defeat, brooding and despair. There is no clear theological education for the hero, but there is a drama of the psyche struggling in earnest with the spiritual life.

2 Edmund Spenser, The Works: A Variorum Edition, "The Faerie Queene, Book one," Ed. Frederick Morgan Padelford (1932; Baltimore: The Johns Hopkins Press, 1966), p. 118. Subsequent quotations are from this edition.

3 Paul J. Alpers alerts us to the power of the imagery in this and like passages to involve the reader in a direct experience. "The immediacy of the reader's psychological experience is the sign of all these episodes - the Red Cross Knight's misery in the Cave of Despair, the menacing glitter of Busyrane's palace, the oppressiveness of Mammon's cave, the seductive otium of the Bower of Bliss." It is an "almost physical contact with his verse" which intensifies the experience. "Narrative and Rhetoric in the Faerie Queene," Elizabethan Poetry, p. 397.

4 John Skelton, The complete Poems of John Skelton, ed. Philip Henderson (London \& Toronto: J.M. Dent and Sons Ltd., 1948), Stage 4. sc. 31.9, p. 236. Subsequent quotations are from this edition.

5 G. Wapull, "The Tide Tarrieth No Man," English Morality Plays and Moral Interludes, ed. Edgar T. Schell and J.D. Shuchter (New York: Holt. Rinehart and Winston Inc., 1969; the 1576 edition, spelling modernized), p. 360.

6 Siegfried Wenzel, The Sin of Sloth Acedia in Medieval Thought and Literature (Chapel Hill: University of North Carolina Press, 1967), p. 184.

7 For further discussions of the role of despair in Marlowe, see Arieh Sachs, "The Religious Despair of Doctor Faustus," J.E.G.P. 63 (1964), pp. 625-47.

8 "The Tide Tarrieth No Man," English Morality Plays and Moral Interludes, p. 362.

9 Burton holds fanatical preaching to be one of the most common means of stirring up religious anxieties. "But the greatest harm of all proceeds from those thundering Ministers, a most frequent cause they are of this malady: and do more harm in the Church (saith Erasmus) than they that flatter; great danger on both sides, the one lulls them asleep in carnal security, the other drives them to despair." (Part 3, Sect. 4, Memb. 2, Subs. 3), Robert Burton, Anatomy of Melancholy, ed. Floyd Dell and Paul Jordan-Smith (New York: Tudor Publishing Company, 1927), p. 941. 
10 Nathaniel Woodes, "The Conflict of Conscience," English Morality Plays and Moral Interludes, p. 545.

11 I am assuming as self-evident that despair is central to Spenser's portrait of the inner life, corroboration for which can be found in a cloud of witnesses going back to Janet Spens who stated that, "For Spenser the chief temptation had always seemed to be accidie, to succumb to that deep, passionate lethargy, which lay in wait for so many in his own day, and which in some form is indeed the chief enemy of spiritual achievement." Spenser's Faerie Queene (London: 1934), p. 130. But I am not entering the discussion as to which of the temptations confronting Redcrosse is the most important, whether pride, despair or another. Harry Rusche takes up this debate, concerned that too great a concentration on despair has resulted in "a distortion of both the allegorical significance and the structural unity of Red Cross Knight's quest and his fight against the sins that threaten the Christian life." "Pride, Humility, and Grace in Book I of The Faerie Queene,"S.E.L. 1500-1900, Vol VII (1967), No 1.p.29. My concern is with the anatomy of the inward psyche and the way it was characteristically understood by the Tudor mind, and with the heights and depressions of that mind, not as sins so much as conditions. My argument is twofold: that as an idea, despair was central to the experience of redemption; and that as a character, Redcrosse was created in the Tudor image and that he was the spiritual counterpart to Hamlet and Jacques. Rusche sees that Redcrosse's attempt to outreason Despaire with classical argument is an act of pride because he relies upon his own powers of intellect rather than upon God's grace, a reading which looks at the episode rhetorically as a simple test of Redcrosse's faith, failing to take into account the very essence of what despair is to the Christian life an what it means for the Tudor reader.

12 Reinhard Kuhn, The Demon of Noontide Ennui in Western Literature (Princeton, New Jersey: Princeton University Press, 1976), pp. 39ff.

13 Kuhn corroborates that "the heights toward which they (the cenobites) strove assumed depths previously unknown, and consequently the sublime bliss they sought must have been menaced by the state of joylessness." p. 42.

14 "Accordingly, since acedia, as we understand it here, denotes sorrow for spiritual good, it is evil on two counts, both in itself and in point of its effect. Consequently it is a sin, for by $\sin$ we mean an evil movement of the appetite...." Saint Thomas Aquinas, The Summa Theologica, trans. Fathers of the English Dominican Province (Chicago, London, Toronto: Encyclopaedia Britannica, Inc., 1952), Vol. I1. 563.

15 As Wenzel explains, "the most distinctive feature of acedia's history ... is not the gradual loss of its spiritual meaning or its deterioration, but rather a continuing process of de-monastization or secularization in the sense that the concept was carried from the monastery to the saeculum, the world outside the cloister." p. 179.

16 For a further discussion of the disappearance of acedia as a coherent theological concept, see Wenzel, pp. $181 \mathrm{ff}$. That the state of grief no longer applied to the bonum divinum, but had become a general condition, undermined its identity as a religious idea and thus the "vice lost its significance in Renaissance and later analyses of moral behaviour."

17 Petrarch, Secretum, ed. E. Carrara, in Francesco Petrarca, Prose, ed. G. Martellotti et al. (Milan: "La letteratura italiana. Storia e testi." No. 7. 1955).

18 Wenzel, p. 186.

19 David of Augsburg, Formula novitiorum, 51 (Migne, xiii, 438), quoted (in translation) by Wenzel, p. 160, who also gives on p. 246 references to similar passages in other writers.

20 Timothy Bright, A Treatise of Melancholie... (Imprinted at London by Thomas Vautrollier, dwelling in the Black-Friers, 1586), p. 184.

21 Bright, p. 186.

22 Bright. pp. 188-189.

23 Bright, p. 189.

24 Burton, Anatomy of Melancholy, (Part 3. Sect. 4. Memb. 2. Sub. 3) p. 939.

25 Bright, p. 195.

26 Bright, p. 199. 


\section{0 / Renaissance and Reformation}

27 Bright, p. 190.

28 See also Paul J. Alpers, The Poetry of the Faery Queene (Princeton, N.J.: Princeton University Press, 1967). (1. vii. stanzas 1-7. pp. 142-43.) Maurice Evans also considers the passage to be dealing with a state of sloth which, in itself, does not represent an entirely sinful state. Spenser's Anatomy of Heroism (Cambridge: Cambridge University Press, 1970), p. 100. Yet Redcrosse chooses pleasure over the hard and confusing course of virtue, because he has lost the vision necessary to carry on with the battle of conscience. Whether his encounter with the fallen nymph is sin or merely innocent diversion, it is the attempt at pleasure which gives no comfort or satisfaction, puts him out of his moral armour, and preludes his deepest descent into spiritual defeat.

29 M. Pauline Parker, The Allegory of the Faerie Queene (Ox ford: Oxford University Press, 1962), p. 85.

30 Parker, p. 84. 